\title{
Convolvulaceae do Parque Estadual do Juquery, Franco da Rocha, SP, Brasil
}

\author{
[ำ $\underline{\text { Simone Soares da Silva }}{ }^{1,2,3}$, Rosângela Simão-Bianchini ${ }^{1}$ e Fátima Otavina de Souza-Buturi ${ }^{1,2}$
}

Recebido: 7.10.2017; aceito: 6.06.2018

\begin{abstract}
Convolvulaceae from Parque Estadual do Juquery, Franco da Rocha, São Paulo State, Brazil). The Juquery State Park (PEJ) is the most important Cerrado remnant in the metropolitan region of São Paulo. It is currently under great pressure caused by the human activities arising from the real estate growth in its surroundings. The present study aims to contribute to the knowledge of Convolvulaceae from PEJ. We analyzed herbarium material and included new collections. Field expeditions were carried out from August 2016 to July 2017. As a result, we recognized 13 species distributed in four genera: Convolvulus L. (one specie), Distimake Raf. (three), Evolvulus L. (one), and Ipomoea L. (eight). It should be noted that two of these species are ruderal, indicating that the Park can be under influence of human activities. An identification key for species is presented, along with descriptions for genera and species, photos, comments on the taxonomy and distribution of each species.
\end{abstract}

Keywords: biodiversity, bindweed, lianas, open fields

RESUMO - (Convolvulaceae do Parque Estadual do Juquery, Franco da Rocha, SP, Brasil). O Parque Estadual do Juquery (PEJ) é o mais importante remanescente de Cerrado na região metropolitana de São Paulo. Atualmente, o PEJ sofre grande pressão devido às atividades antrópicas, como consequência do crescimento imobiliário dos entornos. O objetivo do presente estudo é contribuir com o conhecimento de Convolvulaceae para o PEJ. Foram utilizados materiais de herbário enriquecidos com novas coletas. As viagens a campo foram realizadas de agosto de 2016 a julho de 2017. Como resultado, foram reconhecidas 13 espécies distribuídas em quatro gêneros: Convolvulus L. (uma espécie), Distimake Raf. (três), Evolvulus L. (uma) e Ipomoea L. (oito). Nota-se que duas dessas espécies são ruderais, indicando que o Parque pode estar sofrendo influência das atividades humanas. Apresenta-se chave de identificação das espécies ocorrentes no PEJ, seguida de descrições para gêneros e espécies, fotos, e comentários referentes à taxonomia e à distribuição de cada espécie.

Palavras-chave: biodiversidade, campos abertos, corda-de-viola, trepadeiras

\section{Introdução}

Convolvulaceae conta com aproximadamente 60 gêneros e 1.900 espécies, agrupadas em 12 tribos (Staples 2012, Mitchell et al. 2016). É caracterizada por espécies de ervas, subarbustos ou arbustos, de hábito volúvel, prostrado ou ereto, ocasionalmente árvores ou ainda um gênero de holoparasitas (Delgado Júnior et al. 2014). As folhas são alternas, inteiras ou compostas (Simão-Bianchini \& Pirani 1997). As inflorescências são cimosas, em geral de flores vistosas, dialissépalas e gamopétalas, 5-meras, com cinco estrias mesopétalas bem delimitadas (Austin \& Cavalcanti 1982, Ooststroom \& Hoogland 1953,
Staples 2012). Em geral, o fruto é seco capsular loculicida ou loculicida e septícida, raro indeiscente ou baga (Simão-Bianchini \& Pirani 1997).

Possui distribuição cosmopolita com predomínio nos trópicos e poucos representantes nas regiões temperadas (Austin 1975, Simão-Bianchini 1991, Staples 2012). AAmérica do Sul está dentre os quatro maiores centros de diversidade da família (McDonald 1991). No Brasil sua ocorrência é abundante, com registros em todas as regiões, com predomínio nos biomas Cerrado, Caatinga e Mata Atlântica (Flora do Brasil 2020 [em construção]), sendo os gêneros mais representativos Ipomoea, Evolvulus e Jacquemontia Choisy (Buril \& Alves 2011).

1. Instituto de Botânica, Núcleo de Pesquisa Curadoria do Herbário SP, Av. Miguel Estéfano 3687, Água Funda, 04301-902 São Paulo, SP, Brasil

2. Universidade São Judas Tadeu, Rua Taquari 546, Mooca, 03166-000 São Paulo, SP, Brasil

3. Autor para correspondência: moness1986@yahoo.com.br 
Dentre os diversos usos atribuídos a algumas espécies destaca-se a importância econômica de Ipomoea batatas L., a batata-doce, que é utilizada em todo o mundo como alimento para o homem e para o gado ou como matéria prima para a produção de álcool (Hoehne 1922, Austin 1975, Simão-Bianchini 2002, Staples 2012, Moura \& Morim 2015) e I. aquatica Forssk. bastante empregada como alimento na culinária asiática (Austin 2007, Staples 2012). Como ornamental, são utilizadas várias espécies por conta da beleza de suas flores (Austin 1975, Simão-Bianchini 1991, Lorenzi \& Souza 1995) e também são muitas aquelas com valor medicinal (Hoehne 1922, Rodrigues et al. 2001), além de espécies tóxicas, destacando Ipomoea carnea Jacq. (Hoehne 1922, Kissmann \& Groth 1992).

O Estado de São Paulo foi pouco visitado pelos naturalistas e botânicos que percorreram o Brasil em diferentes períodos ao longo da elaboração da "Flora Brasiliensis", realizado por Martius et al. 1840-1906, mesmo assim, esta constitui a obra mais completa e representativa elaborada para a Flora do Brasil (Shepherd 2005). Posteriormente raros estudos contribuíram para o conhecimento de Convolvulaceae no Estado de São Paulo: Simão-Bianchini (2005), Wanderley et al. (2011), Pastore \& Simão-Bianchini (2017), e atualmente uma importante contribuição está disponível na "Flora do Brasil 2020" (Flora do Brasil 2020 [em construção]). No entanto, ainda há regiões que carecem de estudos taxonômicos, visando um levantamento mais detalhado da flora local, como é o caso do Parque Estadual do Juquery (PEJ).

O PEJ é um dos poucos remanescentes do Cerrado que ainda resiste à pressão urbana na Região Metropolitana de São Paulo. Está inserido na sua porção Noroeste, entre os municípios de Franco da Rocha e Caieiras, onde abriga uma ampla diversidade de plantas e animais, inclusive espécies ameaçadas de extinção (Futada et al. 2012, Sistema Ambiental Paulista 2017).

No Parque Estadual do Juquery foi realizado um importante levantamento florístico por Baitello et al. (2013) que demonstrou dentre outros aspectos, sua grande diversidade florística, onde Convolvulaceae foi representada por nove espécies.

Ao fazer uma busca referente aos estudos desenvolvidos em fragmentos de Cerrado e de mata no Estado de São Paulo, percebe-se que boa parte não contabilizou espécies de Convolvulaceae, uma vez que muitos desses estudos não contemplaram o estrato herbáceo e as lianas, como exemplo destacam-se os trabalhos de Pereira-Silva et al. (2004), Reys et al. (2013) e Carvalho et al. (2013), evidenciando assim a importância do presente estudo para o conhecimento da família neste tipo de bioma tão ameaçado.

Desta forma, o presente estudo objetivou realizar o levantamento taxonômico de Convolvulaceae no PEJ, contribuindo assim para a elaboração do seu plano de manejo e também colaborar com informações tanto para o desenvolvimento do projeto "Flora Fanerogâmica do Estado de São Paulo" quanto para o conhecimento da família no Cerrado, de forma a melhorar a correta circunscrição das espécies, visto que muitas são utilizadas na medicina popular.

\section{Material e métodos}

Área de Estudo - O PEJ possui 2.058,09 hectares de território e tem como ponto mais alto o local conhecido como morro Ovo da Pata, a 942 m de altitude (Futada et al. 2012), está inserido entre os municípios de Franco da Rocha e Caieiras. É constituído por uma área semimontanhosa com vertentes mamelonizadas, sendo essas formações típicas do Planalto Paulista, com vegetação dominante de Cerrado e formações vegetais do tipo Campo-limpo, Campo-sujo e Campo-cerrado (Baitello et al. 2013), possuindo ainda, de acordo com Raimundo (2006) fitofisionomias de mata de fundo de vale e remanescentes de Floresta Ombrófila Densa, reunindo assim uma flora extremamente representativa, principalmente por ser considerado uma importante área remanescente de Cerrado na Região Metropolitana de São Paulo (Miura 2009).

O solo da região é propício ao desenvolvimento deste tipo de vegetação, com exceção das manchas de latossolos vermelho escuro argilo-arenosos (Baitello et al. 2013) que são rasos, provavelmente indicando os antigos cambissolos, cuja a espessura raramente ultrapassa $1 \mathrm{~m}$, com horizonte organomineral, o que justifica a ausência de extensas formações florestais (Raimundo 2006).

O clima ao qual essa vegetação se instalou, remete ao tempo seco predominante do período quaternário, que permitiu assim, a configuração destas manchas de Cerrado isoladas, em um ambiente de domínio da Mata Atlântica (Raimundo 2006). Segundo dados de Futada et al. (2012) atualmente a região sofre influência do clima mesotérmico úmido, sem estação seca e verão bem definidos, com temperatura média anual em torno de $20^{\circ} \mathrm{C}$.

Coleta e descrição do Material Botânico - Visitas ao PEJ foram realizadas entre os meses de agosto de 2016 
e abril de 2018, em busca de material botânico em fase reprodutiva e também para captura de imagens.

As imagens capturadas registram o hábito, as inflorescências, o detalhe lateral das flores mostrando as sépalas e o formato da corola.

Para as coletas e preparo do material botânico seguiu o método proposto por Mori et al. (1999) e as exsicatas foram incorporadas à coleção do herbário SP (Instituto de Botânica).

As descrições foram elaboradas com base nas análises realizadas nos materiais provenientes do PEJ, coletados por Baitello et al. (2013) e pelos autores durante as viagens de coleta do presente trabalho e, quando necessário, foram complementadas com materiais de outras localidades (material complementar) depositados nos Herbários SP, SPSF e SPF.

As estruturas foram caracterizadas, medidas com uma régua e os dados agrupados em uma planilha do Microsoft Excel, os quais foram utilizados na elaboração das descrições e da chave de identificação. Nas folhas compostas e lobadas a medida do comprimento foi baseada no maior folíolo, enquanto que para se medir a largura considerou-se a folha como um todo. Os dados referentes as brácteas foram omitidos, pois todas as espécies analisadas possuem brácteas foliáceas com medidas iguais às das folhas.

A terminologia utilizada para descrição das espécies seguiu Redford et al. (1974), para caracterização do hábito, estruturas foliares e indumento e Weberling (1989) para caracterização das inflorescências. Para melhor compreensão dos termos usados nas descrições originais das espécies adotou-se o Dictionary of Botanical Therms (Henslow 2009).

As características do gineceu e androceu foram importantes para o processo de identificação do material coletado, porém estas não puderam em sua totalidade ser medidas para as descrições aqui apresentadas, pois o material para estudo proveniente do PEJ é escasso e as características das suas formas são importantes para classificação genérica e não de espécie, estas foram incluídas na introdução de cada gênero, baseadas em informações da literatura e de acordo com o que foi observado e, na descrição das espécies quando não analisadas utilizou-se a expressão "não visto".

\section{Resultados}

Na lista elaborada por Baitello et al. (2013) Convolvulaceae está representada por nove espécies no PEJ. A partir das novas coletas e reidentificação foram reconhecidas 13 espécies pertencentes a quatro gêneros: Convolvulus (1), Distimake (3), Evolvulus (1) e Ipomoea (8). Quanto ao hábito têm-se: uma erva prostrada, três são ervas volúveis, cinco ervas prostradas a volúveis, um subarbusto volúvel e três subarbustos eretos. Oito espécies foram coletadas na área de Cerrado sensu stricto, enquanto cinco foram encontradas em área de borda de mata, principalmente espécies do gênero Ipomoea. Convolvulus crenatifolius, Ipomoea cairica, Ipomoea regnellii, Ipomoea nil e Ipomoea triloba são registradas para a região pela primeira vez. Todas as espécies observadas apresentam antese diurna. Distimake tomentosus é a espécie mais comumente encontrada ao longo das trilhas e foi coletada em flor ou fruto durante grande parte dos meses do ano. Quatro espécies são consideradas ruderais ( $D$. macrocalyx, I. cairica, I. nil e I. triloba) de acordo com Lorenzi (1991) e Kissman \& Groth (1999), demonstrando assim o aumento da vulnerabilidade do PEJ à pressão antrópica dos entornos, uma vez que destas consideradas ruderais, apenas $D$. macrocalyx já havia sido citada para o Parque.

\section{Convolvulaceae}

Ervas, subarbustos ou arbustos, muito raro árvores, ramos frequentemente volúveis ou rasteiros, prostrados, eretos, e um gênero de holoparasitas representado por Cuscuta L. Comumente apresentam látex, células oleíferas já observadas em diversas espécies. Indumento variável, formado por tricomas simples, malpiguiáceos, estrelados, escamiformes ou glandulares. Sistema subterrâneo pivotante, desenvolvido em algumas espécies formando raízes tuberosas. Folhas alternas, simples, inteiras, palmatilobadas, pinatilobadas, raro palmaticompostas, sésseis ou pecioladas, às vezes reduzidas a escamas, por vezes apresentam nectários extraflorais no ápice do pecíolo. Inflorescência cimosa, uni ou multiflora, axilar ou terminal, formada por dicásios, tirsos amplos, glomeruliformes, capituliformes ou racemiformes; brácteas em geral iguais às folhas. Flores hermafroditas, com tamanhos e cores variados, frequentemente vistosas, antese quase sempre diurna, apresentando um par de bractéolas por pedicelo. A prefloração contorcida é bastante característica para a família. Sépalas 5, livres, raramente soldadas na base como em Cuscuta e Cressa L., imbricadas, iguais ou desiguais, persistentes, ocasionalmente acrescentes 
na frutificação. Corola gamopétala, actinomorfa, usualmente 5-mera, raro 4-mera, infundibuliforme, campanulada, tubular ou hipocrateriforme, raro rotácea ou urceolada, com 5 áreas mesopétalas bem delimitadas, glabras, pilosas ou pubescentes externamente. Estames (4-) 5, distintos, basifixos, adnatos ao tubo da corola, inclusos ou exsertos, isômeros ou notavelmente desiguais, alternos aos lobos da corola, filetes filiformes usualmente dilatados na base, apresentando ou não indumento glandular. Anteras base ou dorsifixas, ovadas, oblongas ou lineares, com deiscência longitudinal, introrsa ou lateral, base sagitada ou auriculada. Ovário súpero, 2 (-3) carpelar, formando (1-) 2-4 lóculos, raro 6-locular ou 1-locular com 4 óvulos, em geral são 2 óvulos por carpelo. Estilete comumente único, filiforme simples, bífido ou 2 estiletes distintos ou ainda 2 ginobásicos. Estigma terminal, inteiro, captado ou 2-lobado, raro 3-lobado, ou estigmas 2-4, globular ou elipsoide a filiforme, às vezes aplanados, geralmente papilosos. Nectário anular ou urceolado, cercando a base do ovário, sendo pouco notável ou ausente. Fruto em geral seco capsular, com cálice persistente, raro baga, subgloboso ou ovoide com deiscência geralmente septícida e loculicida, menos comum apenas septícida, circular (opercular), valvar, irregular ou indeiscente, 1-4 locular. Sementes tantas quantas ou menos que os óvulos, glabras ou com indumento diversificado, embrião plicado ou curvado, cotilédones foliáceos emarginados ou bilobados, raro inteiros ou ausentes. A família é classificada como euripolínica, apresentando aberturas, tamanhos e ornamentação variados (Austin 1975, Austin \& Cavalcante 1982, Simão-Bianchini 1991, 1998, Staples 2012, Simão-Bianchini et al. 2016).

Chave para as espécies de Convolvulaceae ocorrentes no Parque Estadual do Juquery

1. Folhas simples e inteiras

2. Flores sésseis; corola hipocrateriforme, azulada Evolvulus aurigenius var. macroblepharis

2. Flores pedunculadas; corola campanulado-infundibuliforme, branca ou lilás

3. Erva, ramos prostrados a volúveis

4. Folhas deltoides, base sagitada, velutinas; corola branca Convolvulus crenatifolius

4. Folhas estreito-elípticas ou ovadas, base cordada ou arredondada, velutinas, seríceas a glabras; corola lilás a azulada

5. Folhas estreito-elípticas, base arredondada, glabras; sépalas glabras Ipomoea procumbens

5. Folhas ovadas, base cordada, seríceas a velutinas; sépalas seríceas Ipomoea regnellii

3. Subarbustos, ramos eretos

6. Ramos e folhas tomentosos, tricomas estrelados Distimake tomentosus

6. Ramos e folhas com indumento variável, tricomas simples

7. Folhas lineares (até $1 \mathrm{~cm}$ larg.); vilosas, glabrescentes, indumento alvo Ipomoea aprica

7. Folhas oblanceoladas a elípticas (1-4,5 cm larg.); denso-seríceas a tomentosas, indumento dourado Ipomoea argentea

1. Folhas simples e lobadas ou compostas

8. Folhas lobadas, 3-5 lobos

9. Ramos esparso-vilosos, corola hirsuta

9. Ramos hirsutos, corola glabra

10. Sépalas estreito ovadas a estreito elípticas, ca. 2,5 cm compr., ápice longo acuminado

10. Sépalas ovadas a elípticas, até $0,5 \mathrm{~cm}$ compr., ápice agudo . Ipomoea nil

8. Folhas compostas

11. Ramos estriados com pseudo estípulas; folíolos basais 2-3 lobados; corola lilás ..... Ipomoea triloba

11. Ramos lisos; folíolos basais não lobados, corola branca, tubo branco ou amarelado

12. Ramos com tricomas simples e glandulares; sépalas estreito-ovadas (ca. 1,5 cm compr.), ápice longo acuminado, hirsutas; corola branca, interior tubo branco Ipomoea cairica 2. Ramos glabros, ocasionalmente com tricomas simples próximo ao pecíolo; sépalas oblongas a elípticas (ca. $3 \mathrm{~cm}$ compr.), ápice arredondado a agudo, glabras; corola branca, interior do tubo amarelado Distimake macrocalyx 


\section{Convolvulus L.}

\subsection{Convolvulus crenatifolius Ruiz \& Pav., Fl. Peruv.}

2: 10.1799 .

Figura $1 \mathrm{a}-\mathrm{b}$

Erva; ramos prostrados a volúveis, vilosos, glabrescentes, tricomas simples em toda a planta, látex ausente, entrenós $3-5,5 \mathrm{~cm}$. Folhas simples, inteiras, deltoides, 3,5-5,3 × 1,5-2,3 $\mathrm{cm}$, base sagitada, margem crenada, ápice arredondado, mucronado, velutina em ambas as faces; pecíolo 0,5-1 cm. Inflorescência em tirso indeterminado, dicásios 1-3 flores; pedúnculo 0,5-4,7 cm; bractéolas lanceoladas, até $2 \mathrm{~mm}$ compr., glabras; pedicelo 0,2-1 cm; sépalas subiguais, obovadas, $0,8 \times 0,4-0,7$ $\mathrm{cm}$, verde acastanhadas in vivo, externas mais escuras e coriáceas, internas bege, papirácea, ápice arredondado a emarginado, mucronulado, indumento seríceo, glabrescente, ciliadas; corola infundibuliforme, $1,6-1,8 \times$ ca. $2 \mathrm{~cm}$, branca, tubo $0,6 \mathrm{~cm}$ larg., levemente rosado internamente, estrias mesopétalas vilosas, ápice barbado; filetes 7-9 mm, anteras oblongas, 1,5 mm compr.; ovário 2-locular, presença de falso septo, glabro, 2 óvulos por lóculo; estilete ca. $9 \mathrm{~mm}$ compr.; estigma filiforme, bipartido, papiloso, branco (in vivo), ca. $5 \mathrm{~mm}$ compr. Cápsula globosa, ca. $1 \mathrm{~cm}$ compr., 4-valvar, glabra; sementes globosas a obovoides, ca. 0,5 cm compr., nigrescentes, glabras.

Material examinado: BRASIL. SÃo PAULO: Franco da Rocha, Parque Estadual do Juquery, trilha principal que leva à pista de pouso, campo, 17-XI-1948, G. Hashimoto 20725 (SP). Idem, 26-I-2017, S.S. Silva et al. 2 (SP).

Material adicional examinado: BRASIL. SÃo PAULO: Parque Estadual do Jaraguá, Região mais alta do Parque, 8-XI-2013, K. Beraldo 38 (SP).

Possui ampla distribuição na América do Sul e no Brasil ocorre nas Regiões Sul e Sudeste, em vegetação de Cerrado (cerrado lato sensu, campo de altitude, campo limpo), Mata Atlântica e mata de transição, podendo também ser encontrada em áreas antropizadas (Wood et al. 2015a, Flora do Brasil 2020 [em construção]).

$\mathrm{O}$ indumento das sépalas internas concentra-se apenas na região mediana e o tom rosado no interior da corola só é possível ser visualizado em indivíduos vivos.
Esta espécie é morfologicamente semelhante a $C$. hermanniae L'Hér. (espécie não ocorrente na área), no entanto, difere especialmente por esta possuir indumento hirsuto no ápice do ovário (e do fruto), outra característica distintiva são suas sépalas que possuem o ápice frequentemente agudo a acuminado.

\section{Distimake Raf.}

Ervas, raro subarbustos; ramos volúveis ou eretos. Folhas frequentemente 5-7-palmatífidas ou palmatilobadas, raramente simples ou reduzidas a escamas. Cálice geralmente com sépalas iguais, aplainadas, pressionando o tubo da corola; corola frequentemente branca ou amarela, raro rosada, com o interior do tubo da mesma cor ou vermelho-escuro a vináceo, glabra, estrias mesopétalas com nervuras por vezes mais escuras; anteras espiraladas após a antese; estilete único com dois estigmas globosos. Cápsula 4-valvar, sépalas acrescentes, reflexas; sementes glabras, raro curto-velutinas a glabrescentes. Pólen tricolpado (Simões \& Staples 2017, Petrongari et al. 2018). Gênero de ampla distribuição na América e África tropical com algumas espécies registradas na Ásia e Norte da Austrália (Simões \& Staples 2017).

\subsection{Distimake hirsutus (O'Donell) Petrongari \&}

Sim.-Bianch., Phytotaxa 340: 298. 2018.

Figura $1 \mathrm{c}-\mathrm{g}$

Erva; ramos lisos, prostrados a volúveis, hirsutos, tricomas simples entremeados por tricomas glandulares capitados mais denso no ápice dos ramos, látex branco abundante; entrenós 3,2-8,3 cm. Folhas 5-palmatífidas, 2,5-5,5 × 2-4,5 cm, folíolos elípticos a oblanceolados, base obtusa, margem serreada, ápice arredondado, agudo a obtuso, mucronado, glândulas punctadas, face abaxial esparso-hirsuta nas nervuras, margem esparso-ciliada, glabrescente, tricomas simples, estrigosos; pecíolo 0,2-0,4 cm, indumento hirsuto, tricomas simples e glandulares capitados. Inflorescência axilar pauciflora, 1-3 flores; pedúnculo 0,2-0,4 cm; bractéolas estreito lanceoladas, 10-20 mm compr., persistentes, esparso-hirsutas, tricomas simples; pedicelo $0,3-0,5 \mathrm{~cm}$; sépalas iguais a subiguais, estreito-ovadas, 1,3-1,5 × 0,2-0,4 cm, verdes com margem vinácea (in vivo), ápice longo acuminado, indumento hirsuto, glabrescente, tricomas simples; corola campanulado-infundibuliforme, 2,4-3,3 $\times$ ca. $3 \mathrm{~cm}$, branca, glabra, com minúsculas glândulas douradas, tubo 0,5-1 cm larg., branco; filetes alvos, anteras rosadas in vivo, base sagitada, 1-2 mm; 

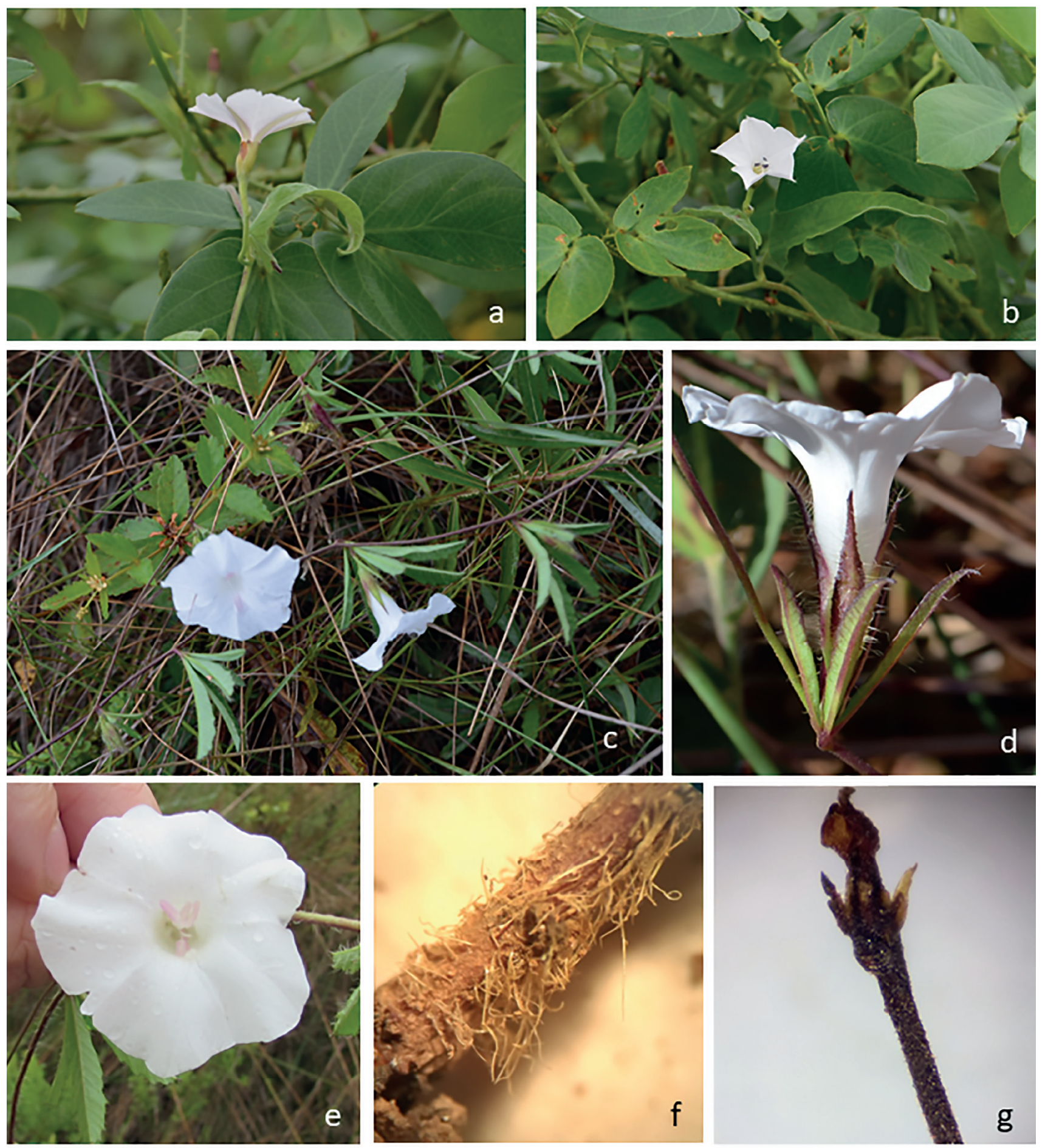

g

Figura 1. a-b. Convolvulus crenatifolius. flor. c-g. Distimake hirsutus. c. Hábito. d-e. Flor. f-g. Diferenciação do indumento entre a área basal dos ramos e o ápice. Fotos a-e: Simão-Bianchini, R.; e-f: Silva, S.S.

Figure 1. a-b. Convolvulus crenatifolius. flower. c-g. Distimake hirsutus. c. Habit. d-e. Flower. f-g. Differenciation of indument between the base of the branch and its apex. Photos: Simão-Bianchini, R.; e-f: Silva, S.S. 
ovário 4-locular, 4-ovulado; estilete ca. $15 \mathrm{~mm}$, arroxeado in vivo; estigma alvo. Cápsula elipsoide, ca. $1 \mathrm{~cm}$ compr., glabra, sementes não vistas.

Material examinado: BRASIL. SÃo PAULO: Franco da Rocha, Parque Estadual do Juquery, 17-III-2003, J.B. Baitello \& F.S. Peres 1475 (SPSF); próximo à pista de pouso, trilha secundária, 12-VI-2015, F.S. Petrongari et al. 28 (SP); 17-I-2002, J.R. Pirani \& J.B. Baitello 4916 (SPF, SPSF, SP); trilha sentido ao morro Ovo da Pata, 26-I-2017, S.S. Silva et al. 3 (SP); trilha que leva para a "árvore solitária", 23-IV-2018, S.S. Silva 23 (SP); 8-VII-2017, S.S. Silva \& R. Simão-Bianchini 7 (SP).

Ocorre apenas no Brasil, nas Regiões CentroOeste e Sudeste, em Cerrado (campo limpo) e na Mata Atlântica (área de transição) (Flora do Brasil 2020 [em construção]).

Difere-se de Distimake cissoides (Lam.) A.R. Simões \& Staples (espécie mais semelhante, mas não ocorrente na área) por possuir tricomas glandulares restritos apenas aos ramos, pecíolos e pedúnculos. As sépalas de ambas também diferem, em $D$. cissoides as sépalas apresentam ápice caudado, enquanto em D. hirsutus são acuminados. Segundo Petrongari et al. (2018) esta espécie vem sendo erroneamente identificada como Merremia cissoides (Lam.) Hallier f. (atual $D$. cissoides), e com esse nome foi incluída na lista de Baitello et al. (2013). Observou-se nas populações estudadas que $D$. hirsutus apresenta tricomas glandulares abundantes no ápice dos ramos, região onde os tricomas simples são escassos, ou mesmo ausentes, sendo estes mais abundantes ao longo dos ramos, aglomerando-se em regiões de contato com o solo, onde os tricomas glandulares são mais raros (figura $1 \mathrm{f}-\mathrm{g}$ ).

\subsection{Distimake macrocalyx (Ruiz \& Pav.) Simões}

$\&$ Staples, Botanical Journal of the Linnean Society 183: 576. 2017.

Nomes populares: batatarana, jetirana.

Figura 2 a-c

Subarbusto; ramos lisos, volúveis, glabros, raros tricomas simples próximo ao pecíolo, látex ausente; entrenós 3,7-11 cm. Folhas 5-palmatífidas, 3,7-6,8 $\times 4,5-11 \mathrm{~cm}$, folíolos recurvados, elípticos, base obtusa, margem inteira, ápice agudo, mucronado, face adaxial glabra raro com tricomas simples esparsos, face abaxial glabra; pecíolo 1,2-3,6 cm. Inflorescência em dicásios, 2-9 flores; pedúnculo 1,7-10 cm; bractéolas triangulares, ca. $3 \mathrm{~mm}$ compr., glabras, geralmente caducas; pedicelo $0,8-2,5 \mathrm{~cm}$; sépalas iguais a desiguais, oblongas a elípticas, 1,8-2,8 $\times 0,7 \mathrm{~cm}$, ápice arredondado a agudo, vináceo, levemente reflexo, glabras; corola campanulada, 3-3,2 × 2,5-4 cm, branca, glabra, tubo ca. 1,5 cm larg., interior amarelo; filetes 1-1,3 cm compr., anteras ca. 0,5 cm compr., alvas; ovário 2-locular, 2 óvulos por lóculo, estilete 2-2,3 cm compr., estigma globoso, 2-globular, ca. $1 \mathrm{~mm}$. Cápsula transversalmente elipsóide, ca $1 \mathrm{~cm}$ compr., glabra; sementes 3 por cápsula, elípticas, ca. $0,5 \mathrm{~cm}$ compr., pubescentes, tricomas simples.

Material examinado: BRASIL. São PAULO: Franco da Rocha, Parque Estadual do Juquery, trilha que leva para a "árvore solitária", 23-IV-2018, S.S. Silva et al. 20 (SP); trilha que leva para a "árvore solitária", 23-IV-2018, S.S. Silva et al. 21 (SP).

Material adicional examinado: BRASIL. São PAULO: Mogi Guaçu, Martinho Prado; Mata do Português, 25-XI-1991, J.V. Godoi \& S. Romaniuc Neto 131 (SP); 17-III-1981, C.M. Oliveira \& W. Mantovani 47 (SP). Porto Ferreira, trilha das árvores gigantes, 10-VI-2010, A.P.C. Oliveira \& F.A.N. Campos 90 (HRCB).

Possui ampla distribuição geográfica, no Brasil ocorre em quase todos os Estados brasileiros, ainda sem registro apenas para o Rio Grande do Sul (Flora do Brasil 2020 [em construção]). Considerada invasora, ocorre tanto em meio a pomares e cultivos, principalmente de café, como em áreas antropizadas. É nativa sendo encontrada em todos os domínios fitogeográficos em borda de mata (Lorenzi 1991, Kissman \& Groth 1999, Flora do Brasil 2020 [em construção]). Possui potencial ornamental ainda pouco explorado (Lorenzi 1991, Kissman \& Groth 1999).

2.3. Distimake tomentosus (Choisy) Petrongari \&

Sim.-Bianch., Phytotaxa 340: 299. 2018.

Nome popular: velame-do-campo

Figura $2 \mathrm{~d}-\mathrm{h}$

Subarbusto 30-40 cm alt.; ramos eretos, tomentosos, tricomas estrelados em toda a planta, látex ausente; entrenós $0,5-2,5 \mathrm{~cm}$. Folhas simples, inteiras, oblongas, 4,5-9,5×1,2-2,2 $\mathrm{cm}$, base arredondada, margem inteira, ápice arredondado a obtuso, mucronado, face adaxial tomentosa, face abaxial denso-tomentosa; pecíolo 0,1-0,5 cm. Inflorescência monocasial, 1-2 flores; pedúnculo $0,3-0,7 \mathrm{~cm}$ ou séssil; bractéolas ovadas, côncavas, ca. $2 \mathrm{~mm}$ compr., tomentosas; pedicelo $3 \mathrm{~mm}$ ou muito reduzido, ca. $0,5 \mathrm{~cm}$ no fruto; sépalas desiguais, elípticas, 

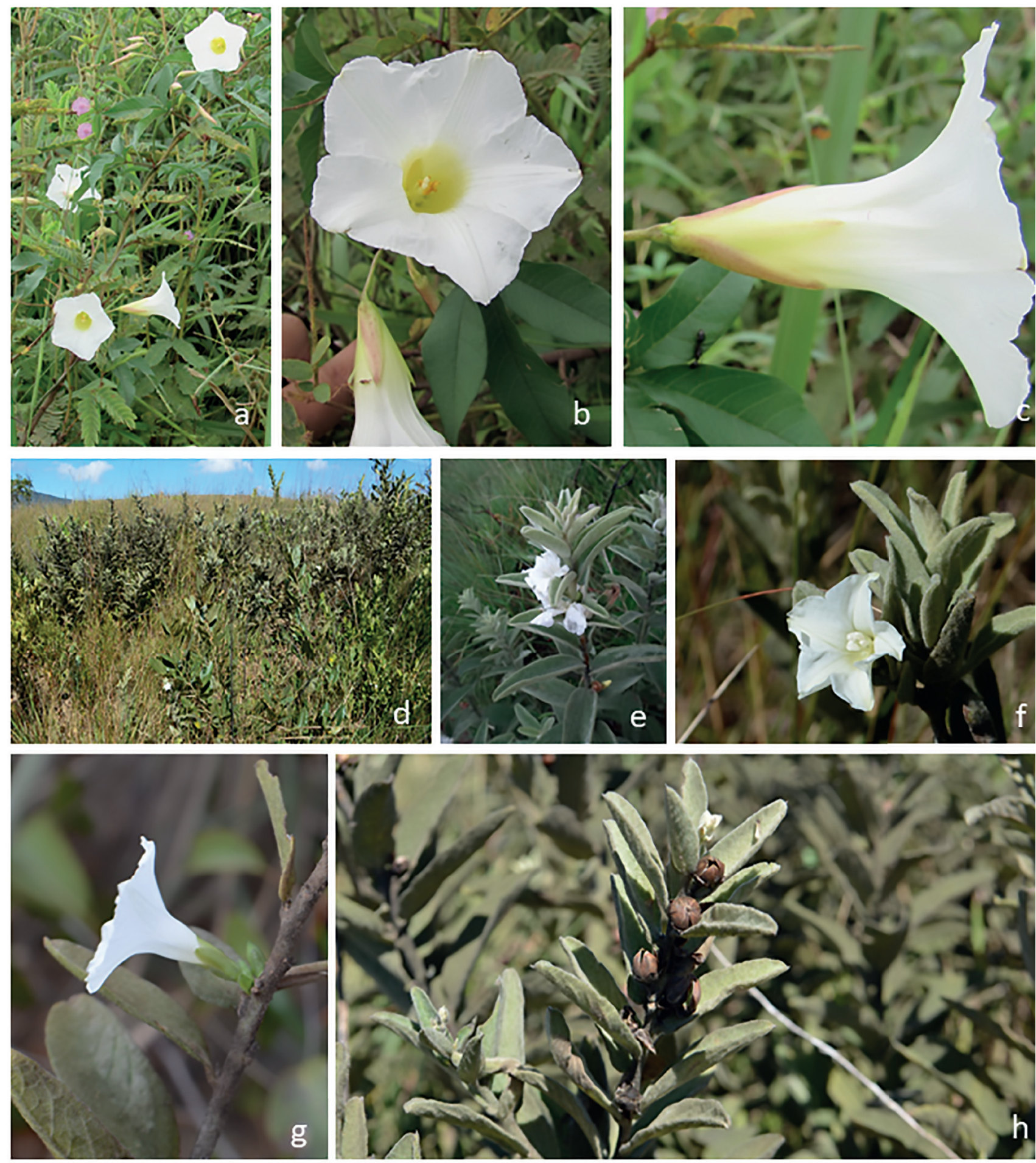

Figura 2. a-c. Distimake macrocalyx. a. Hábito; b-c. Flor. d-h. D. tomentosus. d. População. e. Hábito. f-g. Flor. e. Fruto. Fotos: a-d: Simão-Bianchini, R.; e-h: Silva, S.S.

Figure 2. a-c. Distimake macrocalyx. a. Habit. b-c. Flower. d-h. D. tomentosus. d. Population. e. Habit. f-g. Flower. e. Fruit. Photos: a-d: Simão-Bianchini, R.; e-h: Silva, S.S. 
0,3-1,2 cm $\times 0,1-0,8 \mathrm{~cm}$, ápice arredondado, agudo a obtuso em fruto, internas glabras, externas esparsotomentosas; corola campanulado infundibiliforme, 2,2-3 $\times 2 \mathrm{~cm}$, branca, glabra, tubo 0,5-1 cm larg., interior branco a alvo; filetes $0,6-1 \mathrm{~cm}$, anteras ca. 2-4 mm; ovário não visto, estilete ca. $1,5 \mathrm{~cm}$, estigma bilobular, lóbulos elipsóides. Cápsula globosa, ca. 0,5-1 cm compr., glabra; sementes 2 por cápsula, curto- pubescentes, nigrescentes, tricomas simples.

Material examinado: BRASIL. SÃo PAULO: Franco da Rocha, Parque Estadual do Juquery, 10-XII-1996, J.B. Baitello et al. 1709 (SPSF); 18-I-2001, J.B. Baitello 963 (SPSF); 2-II-2001, J.B. Baitello 914 (SPSF); encosta do morro grande e arredores, 13-I-2001, J.B. Baitello \& F.S. Peres 1427 (SPSF); 27-V-2011, J.R. Pirani \& V. Augusto 6381 (SPF); estrada para o "Ovo da Pata”, 12-VI-2015, Petrongari, F.S. et al. 29 (SP); nos arredores da trilha seguindo para morro Ovo da Pata, distanciando-se dela cerca de $15 \mathrm{~m}, 8$-VII-2017, S.S. Silva \& R. Simão-Bianchini 8 (SP).

Até o momento referida apenas para o Brasil, ocorrendo em todas as Regiões do país, porém com registros apenas em fitofisionomias características de Cerrado (Flora do Brasil 2020 [em construção]).

\section{Evolvulus L.}

\subsection{Evolvulus aurigenius Mart. var. macroblepharis}

(Mart.) Hassl., Repert. Spec. Nov. Regni Veg. 9: 197. 1911.

Figura 3 a-d

Erva ca. $15 \mathrm{~cm}$ compr., ramificada na base; ramos prostrados, hirsutos, tricomas simples e malpiguiáceos; látex ausente; entrenós $0,5-2,0 \mathrm{~cm}$. Folhas simples, inteiras, largo ovadas a reniformes, $0,9-2,1 \times 0,7-2,2 \mathrm{~cm}$, base truncada a cordada, margem inteira, ápice agudo, obtuso, arredondado ou emarginado, mucronulado, face adaxial glabra, face abaxial com tricomas esparsos hirsutos na nervura principal, simples, malpiguiáceos na margem; pecíolo $0,1-0,3 \mathrm{~cm}$. Inflorescência uniflora axilar, pedúnculo ca. $1 \mathrm{~mm}$ ou séssil; bractéolas estreito ovadas a amplo ovadas, ca. $1 \mathrm{~mm}$ compr., glabras; pedicelo séssil; sépalas iguais, estreito-truladas, ca. $0,5 \mathrm{~cm} \times 0,1 \mathrm{~cm}$, ciliada, ápice agudo a acuminado, barbado, tricomas simples; corola hipocrateriforme, ca. $2 \times 1,5 \mathrm{~cm}$, azul-clara a azul-escura, tubo 1-1,5 cm larg., estrias mesopétalas hirsutas, tricomas simples; filetes ca $15 \mathrm{~mm}$, anteras sagitadas, ca. $1 \mathrm{~mm}$; ovário não visto; estilete 2, basalmente unidos; estigma filiforme, bipartido, ca. $5 \mathrm{~mm}$. Fruto e sementes não vistos.
Material examinado: BRASIL. São PAULO: Franco da Rocha, Parque Estadual Juquery, 27-VI-1901, Comissão Geográfica e Geológica 5835 (SP, SPF); 2-II-2001, J.B. Baitello 947 (SPSF); 27-II-2002, J.B. Baitello 1144 (SPSF); estrada na base do "Ovo da Pata”, 12-VII-2015, Petrongari, F.S. et al. 30 (SP); trilha sentido ao morro Ovo da Pata, 26-I-2017, S.S. Silva et al. 4 (SP); subida do morro Ovo da Pata, beirando a trilha, 28-VII-2017, S.S. Silva \& SimãoBianchini 9 (SP)

Até o momento registrada apenas para o Brasil, com ampla distribuição nos Estados de Minas Gerais e São Paulo em regiões de Cerrado e Mata Atlântica (em campos de altitude) (Silva 2008, Flora do Brasil 2020 [em construção]). No PEJ foi observada uma extensa população nos arredores do ponto mais alto do Parque, o morro "Ovo da Pata", além de estar presente esporadicamente em algumas trilhas de altitudes mais baixas.

Alguns autores tem considerado Evolvulus macroblepharis Mart. como espécie distinta de E. aurigenius (Ooststroom 1934, Silva 2008, Flora do Brasil 2020 [em construção]), entretanto, para este trabalho será seguido o conceito de Hassler (1911) e Rodrigues-Lima (2017), que reconhecem variedades para E. aurigenius. Dessa forma, E. aurigenius var. macroblepharis pode ser distinto de E. aurigenius var. aurigenius pelas folhas glabras na face adaxial e esparso hirsuta na abaxial, enquanto na variedade típica as folhas possuem indumento piloso em ambas as faces.

Evolvulus aurigenius var. macroblepharis é morfologicamente muito semelhante à Evolvulus passerinoides Meisn., porém E. passerinoides é um subarbusto de 30-45 cm, com ramos eretos e indumento denso seríceo (Ooststroom 1934), de folhas elípticas e indumento bastante denso na face abaxial e mais esparso na face adaxial, pedúnculo desenvolvido, podendo chegar a $2,5 \mathrm{~cm}$ comprimento, sépalas densopilosas e corola rotácea a infundibuliforme.

\section{Ipomoea L.}

Ervas, subarbustos a arbustos; ramos volúveis, prostrados ou eretos, glabros ou com indumento variável, normalmente apresentam látex. Folhas simples, inteiras ou lobadas, às vezes compostas. Inflorescência axilar, solitária ou em dicásios simples ou compostos, ou ainda, monocásios; sépalas 5, persistentes, imbricadas, variáveis em forma, tamanho e textura; corola campanulada, infundibuliforme, 
hipocrateriforme ou tubular, branca, rosada, vermelha, purpúrea, azul ou raro amarela ou variegada; estames inclusos ou exsertos, unidos próximo à base da corola, com tricomas glandulares pelo menos até próximo a base; ovário cônico, glabro ou pubescente, 2-(4) locular menos frequente 3-locular; óvulos 4 , menos frequente 6-ovular; estilete 1, simples; estigma (1-) 2 (-3), usualmente globoso, podendo ser 2-3 lobado. Cápsula 4-6 valvar; sementes 4 (-6), com 2 faces planas e uma convexa, glabras ou pubescentes (Austin \& Cavalcante 1982, Austin 1998, Austin 2010, Buril et al. 2013, Simão-Bianchini et al. 2016).


Figura 3. a-d. Evolvulus aurigenius var. macroblepharis. a. Hábito. b-c. Flor. d. Variação de cor da corola numa mesma população. Fotos: a-d: Simão-Bianchini, R.

Figure 3. a-d. Evolvulus aurigenius var. macroblepharis. a. Habit. b-c. Flower. d. Corola collor variation in the same population. Photos: a-d: Simão-Bianchini, R. 
estrigosos e adpresos em toda a planta, látex ausente; entrenós $0,3-3,5 \mathrm{~cm}$. Folhas simples, inteiras, lineares, 4,5-10 × ca. $1 \mathrm{~cm}$, base arredondada a decorrente, margem inteira, ápice agudo, mucronado, face adaxial esparso vilosa a glabrescente, face abaxial vilosa, alvos; pecíolo $0,2-0,9 \mathrm{~cm}$. Inflorescência tirsoide, dicásios de 1-3 flores; pedúnculo 0,2-2 cm; bractéolas ovadas, 2-5 mm compr., esparso vilosas; pedicelo $0,4-1,2 \mathrm{~cm}$; sépalas ovadas, desiguais, 0,5-1×0,3-0,5 cm, ápice agudo, arredondado ou retuso, esparso seríceo, glabrescente, margem escariosa esbranquiçada, sépalas internas com indumento concentrado na região mediana, glabrescente no sentido da margem, que é completamente glabra em sua extensão; corola campanulado-infundibuliforme, 2,5-5,7×5 cm, rósea a lilás, tubo 0,5-1,3 cm larg., estrias mesopétalas seríceas, glabrescentes, indumento denso no ápice; estames não vistos; gineceu não visto. Cápsula ovoide, ca. $1 \mathrm{~cm}$ compr., 4-valvar, vestígio do estilete no ápice, glabra; sementes 2 , estreito-elipticas, ca. $0,5 \mathrm{~cm}$ compr., barbadas, tricomas simples.

Material examinado: BRASIL. SÃo PAULO: Franco da Rocha, Parque Estadual do Juquery, 23-XI-2001, J.B. Baitello 1073 (SP, SPSF); 9-I-2003, J.B. Baitello \& F.S. Peres 1332 (SPSF); 9-I-2003, J.B. Baitello \& F.S. Peres 1398 (SPSF).

Material adicional examinado: BRASIL. Minas GeraIs: Unai, Portão central da UHE Queimado, 25-III-2002, G. Pereira Silva et al. 6196 (SP, CENARGEN, CEMIG/CEB).

No Brasil é uma espécie característica do bioma Cerrado (Campo Cerrado e Campo Limpo), tendo registros para as Regiões Norte, Centro-Oeste e Sudeste, também pode ser encontrada mais raramente no Paraguai e Bolívia (Wood et al. 2015b, Flora do Brasil 2020 [em construção]).

No presente estudo esta espécie não foi avistada nem coletada, porém no material do PEJ depositado no Herbário SPSF constam nas etiquetas que os indivíduos foram encontrados em solo pedregoso, florescendo após queimada.

\subsection{Ipomoea argentea Meisn., in Martius, Fl. Bras.7:} 247. 1869.

Subarbusto $0,5-2 \mathrm{~m}$ alt.; ramos eretos, densoseríceos a tomentosos, indumento dourado, tricomas simples, estrigosos em toda a planta, látex ausente; entrenós $0,5-4 \mathrm{~cm}$. Folhas simples, inteiras, oblanceoladas a elípticas, $1-12 \times 1-4,5 \mathrm{~cm}$, base arredondada a atenuada, margem inteira, ápice agudo a arredondado, mucronado, face adaxial denso serícea, mais escura, face abaxial tomentosa, discolor, indumento de ambas as faces dourado; pecíolo 0,2-0,8 cm. Inflorescência em dicásios 1-3 flores; pedúnculo $0,5-1,5 \mathrm{~cm}$ ou séssil; bractéolas estreito triangulares a lineares, 4-6 mm compr., tomentosas; pedicelo $0,5-1 \mathrm{~cm}$; sépalas iguais a subiguais, elípticas a obovadas, ca. $0,8 \times$ ca. $0,5 \mathrm{~cm}$, ápice arredondado a agudo, externas tomentosas, internas tomentosas ao menos na base; corola campanulado-infundibuliforme, 5-7,5 × 2,5-4,5 cm, lilás a rosada ou purpúrea, glabra, tubo 1,7-2,3 cm larg.; estames não vistos, gineceu não visto. Cápsula amplo obovoide a elipsoide, ca. $1 \mathrm{~cm}$ compr., 4-valvar, glabra; sementes 1 por cápsula, estreito-elípticas, ca. $0,5 \mathrm{~cm}$ compr., comosas, indumento dourado, tricomas simples.

Material examinado: BRASIL. São PAUlo: Franco da Rocha, Parque Estadual do Juquery, 3-I-2003, J.B. Baitello 1392 (SPSF).

Material adicional examinado: BRASIL. S̃̃o Paulo: Altinópolis, Morro do Forno, 17-III-1994, W. Marcondes-Ferreira et al. 741 (SP, UEC). MogiGuaçú, 27-I-1981, M. Sugiyama \& W. Mantovani 84 (SP). Pedregulho, 14-I-1997, L.Y.S. Aona \& A.D. Faria 12 (IAC, SP). Pirassununga, cerrado de Emas, 1-III-1945, F. Rawitscher SPF 16913 (SPF, SP); Cerrado de Emas, 2-II-1995, M. Batalha \& S. Aragaki, V.A.Fritsch 339 (SP). São Paulo, Heliópolis, 11-II-1944, G. Hashimoto 4977 (GHSP, SP).

No Brasil pode ser encontrada nas Regiões Centro-Oeste, Sudeste e Sul, ocorrendo em ambiente de Cerrado s.l. Possui registros também para o Paraguai, Venezuela e Colômbia (Wood et al. 2015b, Flora do Brasil 2020 [em construção]).

Esta espécie não foi encontrada durante as visitas realizadas no PEJ. Dados nas etiquetas do material coletado por Baitello et al. (2013), informam florescimento após queimada e ocorrência em afloramentos rochosos ou em solos arenosos, com sépalas acrescidas e rígidas na fase de frutificação.

4.3. Ipomoea cairica (L.) Sweet, Hort. Brit. 2: 287. 1826.

Nomes populares: campainha, corda-de-viola, corriola, jitirana, ipoméia, enrola-semana, jetirana. Figura 4 a-c

Erva; ramos volúveis, estriados, glabros, látex ausente; entrenós $2,5-7 \mathrm{~cm}$, presença de pseudo 

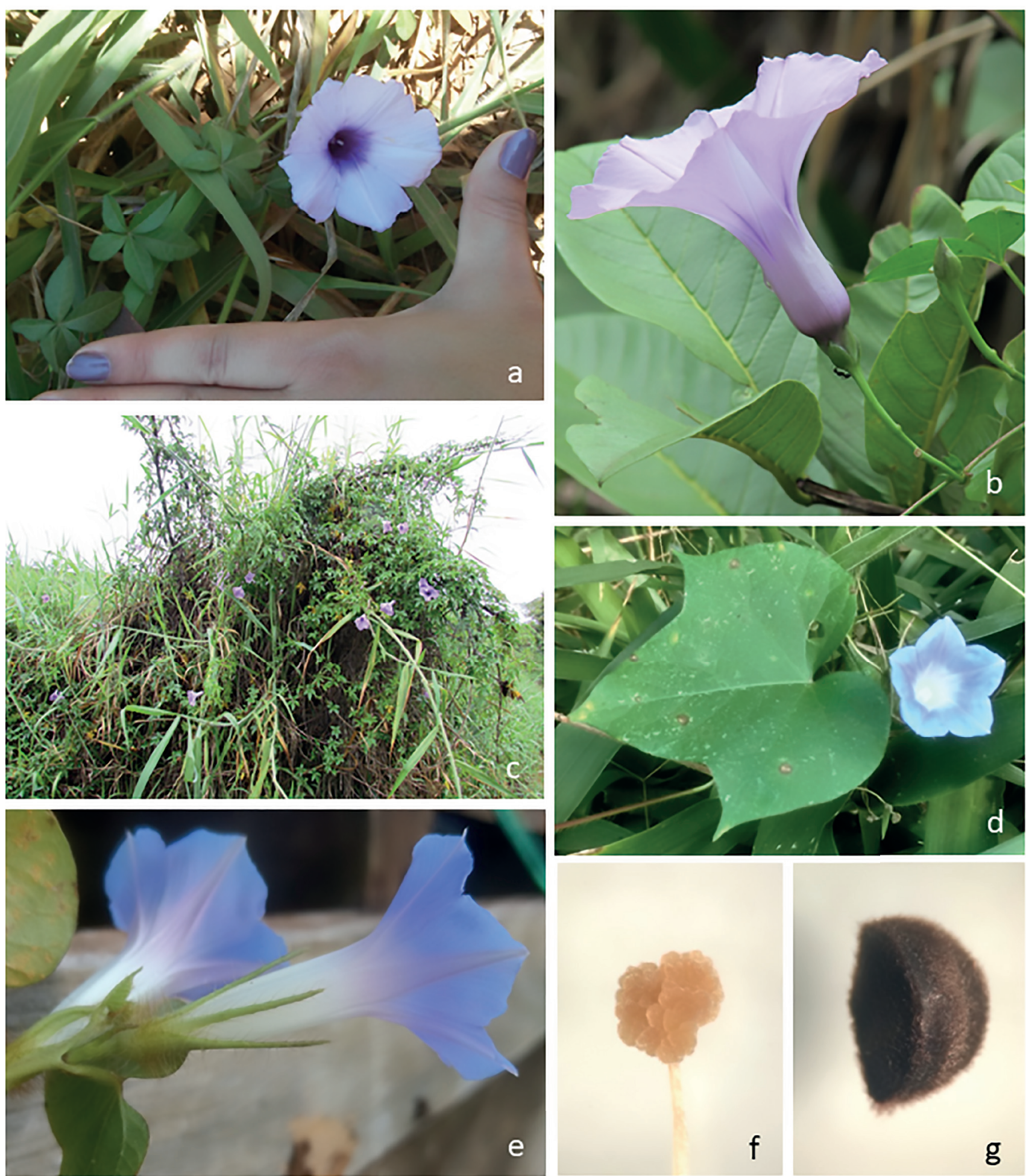

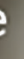

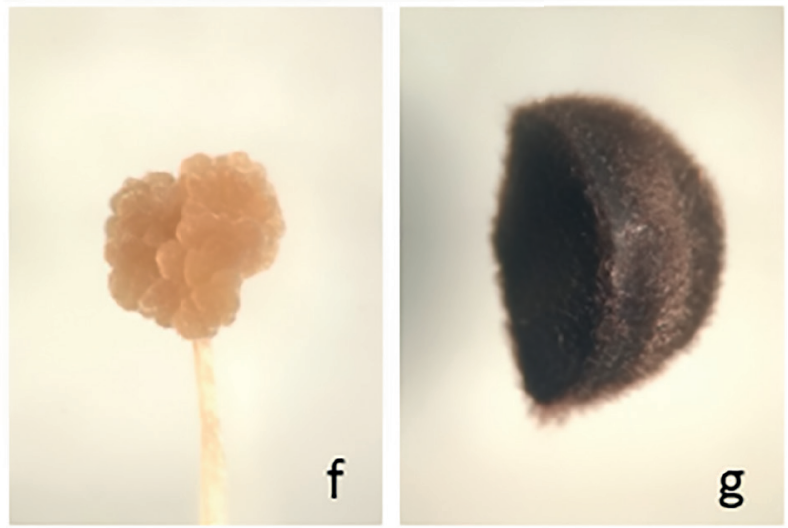

Figura 4. a-b. Ipomoea cairica. a. Hábito. b. Flor. d-g. I. nil. d. Hábito. e. Flor. f. Estigma trilobular. g. Semente trígona. Fotos: a-c: Simão-Bianchini, R.; d-g: Silva, S.S.

Figure 4. a-b. Ipomoea cairica. a. Habit. b. Flower. d-g. I. nil. d. Habit. e. Flower. f. Three lobed stigma. g. Trigonal seed. Photos: a-g: Silva, S.S. 
estípulas lobadas, 3-5 lobos. Folhas 5-palmatilobadas a 5-palmatissectas, 2-7,5 × 4-9,5 cm, folíolos base decorrente, folíolos basais frequentemente 2-3-lobados, margem inteira, ápice arredondado a agudo, mucronado, face adaxial com indumento esparso-puberulente nas nervuras, glabrescente, face abaxial glabra a esparso puberulenta, tricomas simples; pecíolo 0,8-5 cm. Inflorescência em dicásios ou monocásios, 1-3 flores; pedúnculo 0,3-1,5 cm; bractéolas ovadas a oblongas, ca. $1 \mathrm{~mm}$ compr., glabras, caducas; pedicelo ca. $1 \mathrm{~cm}$, sépalas desiguais, ovadas a elípticas, 0,5-0,8 × 0,3-0,6 cm, enrugadas (in vivo), ápice obtuso, emarginado ou arredondado, mucronado, glabra; corola campanuladoinfundibuliforme, 2,3-5,5 × 4-7 cm, lilás claro a lilás escura, glabra, tubo 1-1,5 cm larg., lilás escuro; filetes $1-1,5 \mathrm{~cm}$ compr., anteras sagitadas, ca. $0,5 \mathrm{~cm}$ compr., ovário não visto, estilete ca. $1,5 \mathrm{~cm}$ compr., bipartido no ápice, estigma globular, ca. $1 \mathrm{~mm}$, branco. Cápsula globosa, ca. $1 \mathrm{~cm}$ compr., 4-valvar; sementes 2 por cápsula, elípticas, ca. 0,5 cm compr., seríceas, tricomas simples.

Material examinado: BRASIL. São PAUlo: Franco da Rocha, Parque Estadual do Juquery, trilha que leva para a "árvore solitária" 23-IV-2018, S.S. Silva et al. 22 (SP).

Material adicional examinado: BRASIL. SÃo PAULO: Botucatu, 12-I-1982, Y. Yanagizawa et al. 73 (BOTU, SP); São Paulo, Cantareira, III-1900, A. Puttemans Mus. Paul. 217 (SP); 3-V-1996, J.A. Pastore 668 (SP, SPSF); Parque Tizo, 19-X-2007, S. Honda et al. 143 (PMSP, SP). Pinheiros, 6-V-1934, A. Gehrt 31775(SP).

Espécie amplamente distribuída em regiões tropicais e subtropicais tendo, sua provável origem bastante controversa, pois cogita-se que seja a partir do Velho Mundo e tenha sido disseminada por todo o globo (Wood et al.2015b), em contrapartida, algumas hipóteses a apontam como originária da América, e naturalizada na África e Ásia (Austin \& Ghazanfar 1979, Simão-Bianchini 1998). Existem registros dessa espécie em praticamente todas as regiões do Brasil, ocorrendo desde áreas antropizadas até vegetação mais preservada da Amazônia, Cerrado e Mata Atlântica (Flora do Brasil 2020 [em construção]) e é de comum ocorrência em formações de Floresta Estacional Decidual, Floresta Estacional Semidecidual, Floresta Ombrófila Densa/Aberta, Floresta Ombrófila Mista e Restinga (Moura \& Morim 2015). Possui comportamento infestante e ocorre comumente em áreas perturbadas, porém apresenta potencial paisagístico (Lorenzi 1991, Kissman \& Groth 1999).

Apesar de ser uma planta perene, facilmente encontrada na cidade, no PEJ esta espécie só foi vista na primeira visita ao Parque, para reconhecimento de área e posteriormente não mais avistada. Contudo, na última visita realizada em 2018, foi possível coletá-la em escassa população no domínio Cerrado, em área de campo-sujo. Apesar de já ter sido relatado ocorrência de flores alvas (Kissman \& Groth 1999), a mesma não apresentou significativa variação de cor na corola na população estudada.

\subsection{Ipomoea delphinioides Choisy, Mém. Soc. Phys.} Hist. nat. Genève 8 (1): 53. 1838.

Erva a subarbusto; ramos prostrados a volúveis, raro eretos, esparso-vilosos, tricomas simples, látex ausente; entrenós 0,4-4 cm. Folhas simples, 3-5-lobadas, 3,5-4,7 × 3,5-5,9 cm, base arredondada, margem inteira, ápice arredondado, mucronado, ambas as faces esparso-vilosa, tricomas simples, estrigosos; pecíolo $0,3-0,7 \mathrm{~cm}$. Inflorescência racemiforme, flores axilares solitárias; pedúnculo 2,2-5,9 cm; bractéolas caducas; pedicelo $0,1-0,8 \mathrm{~cm}$; sépalas desiguais, ovadas, $0,8-1,3 \times 0,4-0,5 \mathrm{~cm}$, ápice arredondado a agudo, esparso vilosas, tricomas simples, internas de margens escariosa e esbranquiçada, glabras; corola campanulado-infundibuliforme, 4,5-5,9 × 5,5-7 cm, azulada a lilás claro, hirsuta, tricomas simples, tubo 0,9-1,6 cm larg., estrias mesopétalas glabras; estames não vistos, ginneceu não visto. Cápsula depressa globosa, ca $1 \mathrm{~cm}$ compr., glabra, 4-valvar; sementes 2 por cápsula, elipsoides, ca. $0,5 \mathrm{~cm}$ compr., trifacetadas, dois lados planos e um convexo, seríceas na região angular, tricomas simples.

Material examinado: BRASIL. São PAULO: Franco da Rocha, Parque Estadual do Juquery, 2-II-2001, J.B. Baitello 940 (SPSF); 24-X-2002, J.B. Baitello 1241 (SPSF); 8-X-1997, J.A. Pastore \& J.B. Baitello 819 (SPSF); 19-X-2002, A.C.R. Salles et al. SPF 166590 (SPF).

Material adicional examinado: BRASIL. MINAS Gerais: Poços de Caldas, campos altos e secos, 15-I-19, F.C.Hoehne 2850 (SP).

Ocorre no Paraguai e Brasil, com registros para as Regiões Centro-Oeste, Sudeste e Sul, em Campo Cerrado, Campo Limpo, Campo Rupestre e Mata Atlântica (Ferreira \& Miotto 2009, Rodrigues-Lima 2017, Flora do Brasil 2020 [em construção]). 
Espécie não encontrada nas visitas realizadas ao PEJ. Informações contidas nas etiquetas dos materiais coletados anteriormente no Parque referem florescimento após queimada.

4.5. Ipomoea nil (L.) Roth Catal. Bot.1:36. 1797. Nomes populares: Corda-de-viola, ipoméia Figura $4 \mathrm{~d}-\mathrm{g}$

Erva; ramos volúveis, hirsutos, indumento amerelo claro, tricomas simples em toda a planta, látex ausente, entrenós 11-28,5 cm. Folhas simples, inteiras a 3-lobadas, largo-ovadas, 4,5-12,5 × 3,2-12,5 cm, base cordada, margem inteira, ápice dos lobos laterais agudo, ápice do lobo central agudo a caudado, hirsuta em ambas as faces, face adaxial com indumento em todo o limbo, face abaxial com indumento nas nervuras, raro no limbo; pecíolo $3-13,4 \mathrm{~cm}$. Inflorescência em dicásios 1-3 flores; pedúnculo 0,6-4,7 cm; bractéolas lanceoladas, ca. $5 \mathrm{~mm}$ compr., hirsutas; pedicelo ca. $1 \mathrm{~cm}$; sépalas subiguais, estreito ovadas a estreito elípticas, 2-2,5 $\times 0,3 \mathrm{~cm}$, verdes, lisas, ápice longo acuminado, levemente acastanhado, retilíneo, base hirsuta, ápice esparso hirsuto, quando em fruto tornam-se ovadas a elípticas, ca. $3 \times 0,5-1 \mathrm{~cm}$, textura verrucosa e ápice aristado, encurvado; corola infundibuliforme, 3-4,7 × 1-2,5 cm, azulada, tubo 0,6-1,1 cm larg., branco internamente, glabra; filetes ca. 1,5-2 cm, anteras oblongas, $2 \mathrm{~mm}$ compr., brancas; ovário 3-locular, glabro, 2 óvulos por lóculo; estilete ca. $2 \mathrm{~cm}$ compr.; estigma globoso, 3-lobular, papiloso, branco (in vivo), $2 \mathrm{~mm}$ compr. Cápsula globosa, 0,6-1,2 × $1 \mathrm{~cm}$, papirácea, creme, 4-valvar, glabro; sementes 6 por fruto, levemente ovadas a oblongas, $0,5 \times 0,3 \mathrm{~cm}$, marrons, tomentosas.

Material examinado: BRASIL. São PAULO: Franco da Rocha, Parque Estadual do Juquery, pequena mata localizada atrás dos banheiros da portaria do Parque, 23-IV-2018, S.S. Silva 14 (SP); seguindo 10-20 m após o ponto de bifurcação na trilha, seguindo à esquerda dentro da trilha "Yu Kery", 23-IV-2018 S.S. Silva 16 (SP).

Espécie nativa do Brasil com ampla distribuição em toda a América e introduzida na Ásia (Austin 1986, Simão-Biachini \& Pirani 1997, Nepomuceno et al. 2016). É registrada nos mais diversos domínios fitogeográficos do Brasil, exceto no Pantanal e Pampas (Flora do Brasil 2020 [em construção]). Considerada invasora, frequentemente encontrada em lavouras de soja, milho e outras, além de ocupar terrenos abertos. Devido a beleza das flores possui potencial ornamental, embora pouco explorado (Lorenzi 1991, Kissman \& Groth 1999).

A textura verruculosa das sépalas nos frutos advém do entumescimento do ponto de inserção dos tricomas e pode variar de fruto para fruto no mesmo indivíduo.

4.6. Ipomoea procumbens Mart. ex Choisy, in D.C. Prodr. 9: 351. 1845.

Erva; ramos prostrados a volúveis, estriados, verrucosos, glabros, látex ausente; entrenós 0,5-8,5 cm. Folhas simples, inteiras, estreito-elípticas, 2,5-4 $\times 0,5-1,8 \mathrm{~cm}$, base arredondada, margem carenada, ápice arredondado, mucronado, glabras; pecíolo 0,3-1 cm. Inflorescência em dicásios escorpióides, 1-5 flores; pedúnculo 1-6 cm; bractéolas ovadas, 3-5 mm compr., glabras; pedicelo ca. $1 \mathrm{~cm}$; sépalas ovadas, internas $0,7-1,4 \mathrm{~cm}$, externas 0,4-0,6 cm, ápice emarginado a mucronado, frequentemente papiloso, glabras; corola campanulado-infundibuliforme, 4,5-6,1 × 3,5-5,5 cm, lilás, glabra, tubo $1,8 \mathrm{~cm}$ larg.; estames não vistos, gineceu não visto. Fruto e sementes não vistos.

Material examinado: BRASIL. São PAULO: Franco da Rocha, Parque Estadual do Juquery, 14-II-2002, J.B. Baitello 1115 (SPSF); 17-III-2003, J.B. Baitello 1479 (SPSF).

Material adicional examinado: BRASIL. São PAULO: Pedregulho, P.E. Furnas do Bom Jesus, 20-III-2004, D. Sasaki \& M.F.A. Calió 949 (SP, SPF).

Não considerando variedades em I. procumbens essa espécie é endêmica do Brasil (Austin \& Huáman 1996), com registros para as Regiões Nordeste, Centro-Oeste, Sudeste e Sul, ocorrendo em vegetação de Caatinga (Carrasco) e Cerrado (Campo sujo, Campo cerrado, Campo rupestre e Campo limpo). Porém ao considerar variedades é possivel encontrar registros de ocorrência também para o cerrado do Paraguai e Bolívia (Wood et al. 2015b, Flora do Brasil 2020 [em construção]).

Esta espécie não foi encontrada durante as visitas realizadas no PEJ. Informações contidas nas etiquetas dos materiais complementares caracterizam as folhas como discolores, sendo a face abaxial mais clara.

4.6. Ipomoea regnellii Meisn., in Martius, Fl. Bras. 7: 266.1869.

Figura 5 a-c 

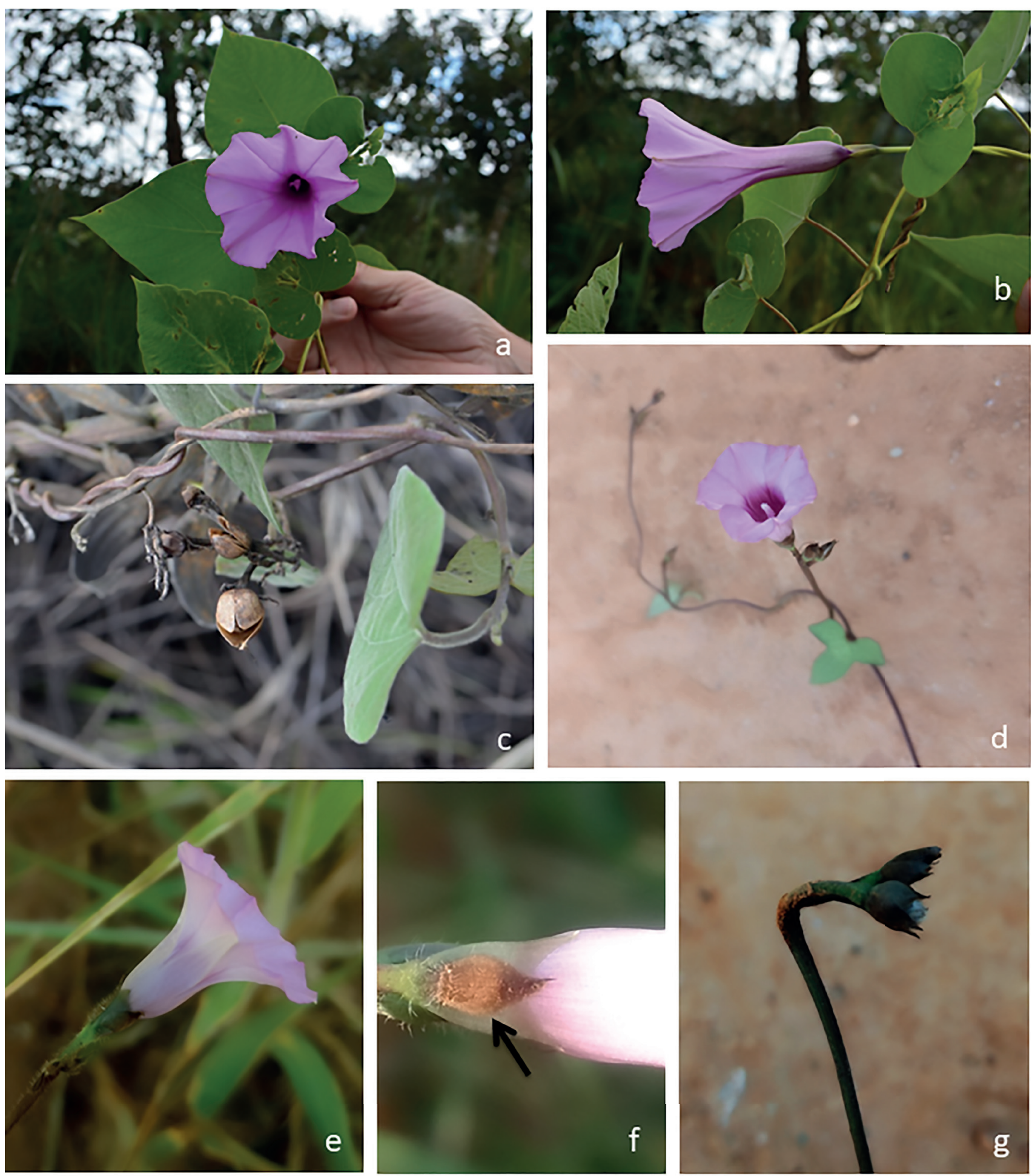

Figura 5. a-c. Ipomoea regnellii. a-b. Hábito e flor. c. Fruto. d-g. I. triloba. d. Hábito. e. Flor. f. Detalhe da sépala externa; g. Fruto com pedúnculo recurvado na maturação. Fotos: a-c: Simão-Bianchini, R.; d-g. Silva, S.S.

Figure 5. a-c. Ipomoea regnelli. a-b. Habit. b. Flower. c. Fruit. d-g . I. triloba. e. Habit. e. Flower. f. External sepal detail. g. Fruit with the peduncle reflexed in the maturation stage. Photos: a-c: Simão-Bianchini, R.; d-g. Silva, S.S. 
Erva; ramos prostrados a volúveis, estriados, puberulentos, glabrescentes, tricomas simples em toda a planta, látex leitoso; entrenós 3,4-10,5 cm. Folhas simples, inteiras, ovadas, 5,5-10 × 3,5-7,6 cm, base cordada, margem inteira, ápice agudo, mucronulado, face adaxial serícea a velutina, face abaxial serícea; pecíolo 1,5-3,5 cm. Inflorescência em tirso indeterminado, dicásios 1-10 flores; pedúnculo 0,3-1,5 cm; bractéolas estreito ovadas a elipticas, ca. $3 \mathrm{~mm}$ compr., serícea a tomentosa; pedicelo 1-2,1 cm; sépalas ovadas, desiguais, $0,7-1,4 \mathrm{~cm}$ compr. lisas, verdes (in vivo), espatuladas, base arredondada a obtusa, ápice arredondado a agudo, indumento seríceo-glabrescente a barbado no ápice, glabras na face interna, margem escariosa; corola campanuladoinfundibuliforme, 3,8-7 × 4,5-8 cm, lilás, esparsoserícea, glabrescente, tubo 0,9-1,5 cm larg., estrias mesopétalas esparso-seríceas, glabrescentes; filete 0,8-1,7 cm, anteras ca. $0,5 \mathrm{~cm}$; estilete ca. $2,5 \mathrm{~cm}$, estigma globoso, 2-lobular. Cápsula ovoide a elipsoide, ca. $1 \mathrm{~cm}, 4$-valvar, glabra, geralmente com vestígio do estilete no ápice; sementes 2 por cápsula, elipsoides, ca. $0,5 \mathrm{~cm}$, denso-seríceas, tricomas simples.

Material examinado: BRASIL. SÃo PAULO: Franco da Rocha, Parque Estadual do Juquery, retorno à portaria do Parque, sentido cachoeira, 8-VII-2017, S.S. Silva \& R.Simão-Bianchini $10(\mathrm{SP})$; próximo à portaria, e também junto a entrada para as trilhas, 26-I-2017, S.S. Silva et al. 1 (SP); trilha que leva para "árvore solitária”, 23-IV-2018, S.S. Silva et al. 18 (SP); idem, 23-IV-2018, S.S. Silva et al. 19 (SP).

Material adicional examinado: BRASIL. SÃo PAULO: Caieiras, 11-IV-1945, W. Hoehne SPF 11485 (SP, SPF); 4-V-1945, W. Hoehne SPF 13371 (SP, SPF).

Amplamente distribuída na América do Sul, sendo que no Brasil foi registrada para as Regiões Norte, Nordeste e Sudeste em formações de mata (Floresta de terra firme, Floresta Ombrófila, Floresta Pluvial) (Wood et al. 2015b, Flora do Brasil 2020 [em construção]).

O indumento nas sépalas internas pode apresentar variação quanto a posição, podendo ser concentrado na região mediana longitudinal ou esparçamente distribuído na região basal.

\subsection{Ipomoea triloba L. Sp. P1. 1: 161. 1753.}

Nomes populares: campainha, corda-de-viola, corriola, jetirana

Figura $5 \mathrm{~d}-\mathrm{g}$
Erva; ramos vináceos, volúveis, presença de três estrias proeminentes, indumento hirsutulo, alvo, tricomas simples em toda a planta, látex branco escasso, entrenós 6,5-17 cm. Folhas simples, 3-lobadas, ovadas, 3-5,5 × 2-4 cm, base auriculada, margem inteira, enegrescida, ápice dos lobos laterais arredondado a acuminado, ápice do lobo central arredondado, mucronado, hirsutula em ambas as faces; pecíolo 0,8-3,5 cm. Inflorescência em dicásios 1-4 flores; pedúnculo 1,5-16 cm; bractéolas estreito triangulares, 2,5-3,5 mm compr., hirsutas; pedicelo 0,4-1 cm, base do receptáculo verde claro (in vivo); sépalas iguais a subiguais, ovadas a elípticas, ca. $0,5 \times 0,2 \mathrm{~cm}$, externas marrons, ressecadas, hirsutas, glabrescentes, internas verdes, glabras, ápice agudo, mucronulado, margens papiráceas, acrescentes e rígidas no fruto, 0,6-0,8 cm compr.; corola campanulado-infundibuliforme, ca. $2 \times 1,5 \mathrm{~cm}$, lilás, tubo ca. $0,5 \mathrm{~cm}$ larg., lilás escuro internamente, glabra; filetes $0,6-0,8 \mathrm{~cm}$, anteras oblongas, sagitadas, ca 1,5 mm compr. rosadas; ovário 2-locular, hirsuto, 1-2 óvulos por lóculo; estilete ca. $1 \mathrm{~cm}$ compr.; estigma globoso, 2-lobular, papiloso, branco (in vivo), ca. $1 \mathrm{~mm}$. Cápsula globosa a elíptica, ca. $0,5 \times 0,5 \mathrm{~cm}$, marrom, hirsuta, indeiscente; sementes 2 por fruto, elípticas, trifacetadas, dois lados planos e um convexo, $0,5 \times 0,2 \mathrm{~cm}$, marrom, glabras.

Material examinado: BRASIL. SÃo PAULO: Franco da Rocha, Parque Estadual do Juquery, na beira do primeiro riacho próximo a portaria e nos entornos da ponte que transpassa o rio, 23-IV-2018, S.S. Silva et al. 17 (SP).

Espécie nativa da América do Sul, ocorre em todos os domínios fitogeográficos do Brasil (Kissman \& Groth 1999, Moura \& Morim 2015, Flora do Brasil 2020 [em construção]). Planta anual, muito comum em cultivos de arroz, soja e áreas abandonadas (Kissman \& Groth 1999).

\section{Espécies Duvidosas}

Houve referência da ocorrência de Ipomoea coccinea L. para o Parque no trabalho de Baitello et al. (2013). Contudo, no presente estudo não foi possível confirmar essa ocorrência, uma vez que não foi localizado material proveniente da área nas viagens de coleta e nem mesmo nas coleções dos herbários. Além disso, segundo O’Donell (1959) I. coccinea não ocorre na América do Sul. Existem duas espécies (Ipomoea hederifolia L.e Ipomoea indivisa (Vell.) Hallier f.) que ocorrem no Brasil e são muito semelhantes à 
I. coccinea, e frequentemente identificadas como $I$. coccinea. Provavelmente é o que ocorreu no caso da listagem de Baitello et al. (2013).

\section{Agradecimentos}

As autoras agradecem ao CNPq, pelas bolsas concedidas (processos 116693/2016-9 e 311738/2016-8); e também à Ana Rita Simões, Bárbara Púglia, Adenilsa Rodrigues Lima, Maria Margarida da Rocha Fiuza de Melo e ao João Batista Baitello, pelos ensinamentos e por toda a colaboração ao longo do desenvolvimento desta pesquisa; e aos Assessores pelas valiosas sugestões necessárias à publicação.

\section{Literatura citada}

Austin, D.F. 1975. Convolvulaceae. In: R.E. Woodson Jr. \& R.W. Schery (eds.). Flora of Panamá. Annals of Missouri Botanical Garden v. 62, pp. 157-224.

Austin, D.F. 1986. Nomenclature of the Ipomoea nil complex (Convolculaceae). Taxon 35: 355-358.

Austin, D.F. 1998. Convolvulaceae morning glory family. Journal of the Arizona-Nevada Academy of Science 30: 61-83.

Austin, D.F. 2007. Water spinach (Ipomoea aquatica, Convolvulaceae): a food gone wild. Ethnobotany Research \& Applications 5: 123-146.

Austin, D.F. 2010. Ipomoea. Convolvulaceae Unlimited. Disponível em http://convolvulaceae.myspecies.info/ taxonomy/term/4439/descriptions (acesso 12-IV-2017).

Austin, D.F. \& Ghazanfar, S. 1979. Convolvulaceae In: Flora of West Pakistan. Islamabad: Agricultural Research Council.

Austin, D.F. \& Cavalcante, P.B. 1982. Convolvuláceas da Amazônia. Belém, Museu Paraense Emílio Goeldi 36: 134.

Austin, D.F. \& Huáman, Z. 1996. A synopsis of Ipomoea (Convolvulaceae) in the Americas. Taxon 45: 3-38.

Baitello, J.B., Aguiar, O.T.A., Pastore, J.A. \& Arzolla, F.A.R.D.P.A. 2013. Parque Estadual do Juquery: refúgio de Cerrado do domínio atlântico. IF Série Registros. 50: 1-46.

Buril, M.T. \& Alves, M. 2011. Flora da Usina São José, Igarassu, Pernambuco: Convolvulaceae. Recife- PE. Rodriguésia 62: 93-105.

Buril, M.T., Delgado-Júnior, G.C., Vasconcellos Barbosa, M.R. \& Alves, M. 2013. Convolvulaceae do Cariri Paraibano, PB, Brasil. Revista Nordestina de Biologia 21: 3-26.

Carvalho, M.B., Bernacci, L.C., \& Coelho, R.M. 2013. Floristic and phytosociology in a physiognomic gradient of riverine forest in Cerrado, Campinas, SP. Biota Neotropica 13: 110-120.
Delgado Júnior, G.C., Buril, M.T. \& Alves, M. 2014. Convolvulaceae no Parque Nacional do Catimbau, Pernambuco, Brasil. Rodriguésia 65: 425-442.

Ferreira, P.P.A. \& Miotto, S.T.S. 2009. Sinopse das espécies de Ipomoea L. (Convolvulaceae) ocorrentes no Rio Grande do Sul, Brasil. Revista Brasileira de Biociências 7: 440-453.

Flora do Brasil 2020 [em construção]. 2018. Jardim Botânico do Rio de Janeiro. Disponível em http:// floradobrasil.jbrj.gov.br/ (acesso 26-II-2018).

Futada, S.M., Spindel, M. \& Ferreira, H.C.L. 2012. Juquery.Unidades de conservação no Brasil, Instituto Socioambiental. Disponível em https:// www.nuestrosParques.org/node/589559 (acesso em 09-V-2018).

Hassler, E. 1911. Repertorium Specierum Novarum Regni Vegetabilis, v. 9, pp. 197.

Hoehne, F.C. 1922. Anexos das memórias do Instituto Butantan- Secção de Botânica. Companhia Melhoramentos de São Paulo 1: 1-103.

Henslow, J.S. 2009. A Dictionary of Botanical Therms. 2 ed. Cambridge University Press, New York.

Kissmann, K.G. \& Groth, D. 1999. Plantas Infestantes e Nocivas. 2 ed. São Paulo. Tomo II. BASF Brasileira SA, São Paulo.

Lorenzi, H. \& Souza, H.M. 1995. Plantas ornamentais no Brasil, arbustivas, herbáceas e trepadeiras. Editora Plantarum Ltda, Nova Odessa.

Lorenzi, H. 1991. Palntas daninhas do Brasil- terrestres, aquáticas, parasitas, tóxicas e medicinais. 2 ed. Editora Plantarum Ltda, Nova Odessa.

Martius, C.F.P. von \& Eichler, A.G. 1840/1906. Flora Brasiliensis: enumeratio plantarum in Brasilia hactenus detectarum. Monachii. Lipsiae. Reimpressão 1965, Verlag von J. Cramer, v. 15.

McDonald, A. 1991. Origin and diversity of mexican Convolvulaceae. Anales del Instituto de Biología. Serie Botánica 62: 65-82.

Mitchell, T.C., Williams, B.R., Wood, J.R., Harris, D.J., Scotland, R.W. \& Carine, M.A. 2016. How the temperate world was colonized by bindweeds: biogeography of the Convolvuleae (Convolvulaceae). BMC Evolutionary Biology 16: 1-12.

Miura, N. 2009. Parque Estadual do Juquery ganha mirantes de observação. Disponível em http://www. ambiente.sp.gov.br/2009/07/14/Parque-estadual-dojuquery-ganha-mirantes-de-observacao/ (acesso em 02-III-2017).

Mori, S.A., Mattos-Silva, L.A., Lisboa, G. \& Coradin, L. 1985. Manual de Manejo do Herbário Fanerogâmico. 2 ed. CEPLAC, Ilhéus.

Moura, A.L.O. \& Morim, M.P. 2015. Convolvulaceae nos remanescentes de Floresta Ombrófita Densa, Rio de Janeiro, Brasil. Rodriguésia 66: 779-805. 
Nepomuceno, S.C., Athiê-Souza, S.M. \& Buril, M.T. 2016. Convolvulaceae da Microrregião do Alto do Capibaribe, PE, Brasil. Hoehnea 43: 371-386.

O'Donell, C.A. 1959. Las especies americanas de Ipomoea L. sect. Quamoclit. (Moench.) Griseb. Lilloa 29: 19-86.

Ooststroom, S. J. 1934. A monograph of the genus Evolvulus. Mededeelingen van het botanisch museum en herbarium van de rijks universiteit te Utrecht 14: 1-267.

Ooststroom, S.J. \& Hoogland, R.D. 1953. Convolvulaceae. In C.G.G.J. Steenis (ed.). Flora Malesiana 1 (4). Noordhoff-Kolff, Djarkata, pp. 388-512.

Pastore, M. \& Simão-Bianchini, R. 2017 Sinopse do gênero Jacquemontia Choisy (Convolvulaceae) no Estado de São Paulo, Brasil: notas nomenclaturais, taxonômicas e geográficas. Hoehnea 44: 611-634.

Pereira-Silva, E., Santos, J.E., Kageyama, P.Y. \& Hardt, E. 2004. Florística e fitossociologia dos estratos arbustivo e arbóreo de um remanescente de cerradão em uma Unidade de Conservação do Estado de São Paulo. Revista Brasileira de Botânica 27: 533-544.

Petrongari, F.S., Simões, A.R. \& Simão-Bianchini, R. 2018. New combinations and lectotypifications in Distimake Raf. (Convolvulaceae). Phytotaxa 340: 297-300.

Raimundo, S. 2006. A paisagem natural remanescente da região metropolitana de São Paulo. São Paulo. São Paulo em Perspectiva 20: 19-31.

Redford, A.E., Dickison, W.C., Massey, J.R. \& Bell, C.R. 1974. Vascular plant systematics. Harper \& Row.

Reys, P., Camargo, M.G.G., Grombone-Guaratini, M.T., Teixeira, A.P., Assis, M.A. \& Morellato, L.P.C. 2013. Estrutura e composição florística de um Cerrado sensu stricto e sua importância para propostas de restauração ecológica. Hoehnea 40: 449-464.

Rodrigues, V.E.G. \& Carvalho, D.A. 2001. Levantamento etnobotânico de plantas medicinais no domínio cerrado na região do Alto Rio Grande - Minas Gerais. Ciência e Agrotecnologia 25: 102-123.

Rodrigues-Lima, A. 2017. Convolvulaceae do Parque Estadual da Serra do Ouro Branco, Minas Gerais, Brasil. Dissertação de Mestrado, Instituto de Botânica, São Paulo.

Silva, C.V. 2008. O gênero Evolvulus L.(Convolvulaceae) no estado de São Paulo e no Distrito Federal, Brasil. Dissertação de Mestrado, Instituto de Botânica, São Paulo.

Simão-Bianchini, R. 1991. Convolvulaceae da Serra do Cipó, Minas Gerais, Brasil. Dissertação de Mestrado, Universidade de São Paulo, São Paulo.
Simão-Bianchini, R. 1998. Ipomoea L. (Convolvulaceae) no Sudeste do Brasil. Tese de Doutorado, Instituto de Biociências da Universidade de São Paulo, São Paulo.

Simão-Bianchini, R. 2002. Importância econômica de Convolvulaceae no Brasil. In: E.L. Araújo E.V.S.B. Sampaio, L.M.S. Gestinari \& J.M.T. Carneiro (eds.). Biodiversidade, Conservação e Uso Sustentável da Flora do Brasil. Recife, Imprensa Universitária, pp. 243.

Simão-Bianchini, R. \& Pirani, J.R. 1997. Flora da Serra do Cipó, Minas Gerais: Convolvulaceae. Boletim de Botânica da Universidade de São Paulo 16: 125-149.

Simão-Bianchini, R., Vasconcelos, L.V. \& Pastore, M. 2016. Flora das cangas da Serra do Carajás, Pará, Brasil: Convolvulceae. Rodriguésia 67: 1301-1318.

Simões, A.R. \& Staples, G. 2017. Dissolution of tribe Merremieae (Convolvulaceae) and a new classification for its constituent genera. Botanical Journal of the Linnean Society 183: 561-586.

Shepherd, G.J. 2005. Flora Brasiliensis: Uma breve história da obra. Disponível em http://florabrasiliensis. cria.org.br/info?history (acesso em 07-I-2018).

Sistema Ambiental Paulista. 2017. Parque Estadual do Juquery- Sobre o Parque- Histórico. Disponível em http://www3.ambiente.sp.gov.br/Parque-estadual-dojuquery/sobre-o-Parque/ (acesso em 02-III-2017).

Staples, G. 2012. Convolvulaceae Unlimited. Disponível em http://convolvulaceae.myspecies.info/node/9\#overlaycontext $=($ acesso 04-VII-2017).

Vasconcelos, L.V., Simão-Bianchini, R. \& França. F. 2016. Two new species of Ipomoea (Convolvulaceae) from the Chapada Diamantina of Bahia, Brazil. Brittonia 68: $142-147$.

Wanderley, M.G.L., Shepherd, G.J., Martins, S.E., Estrada, T.E.M.D., Romanini, R.P., Koch, I., Pirani, J.R., Melhem, T.S., Harley, A.M.G., Kinoshita, L.S., Magenta, M.A.G., Wagner, H.M.L., Barros, F., Lohmann, L.G., Amaral, M.C.E., Cordeiro, I., Aragaki, S., Bianchini, R.S. \& Esteves, G.L. 2011. Checklist of Spermatophyta of the São Paulo State, Brazil. Biota Neotropica 11: 193-390.

Weberling, F. 1989. Morphology of flowers and inflorescences. [Transl. by RJ Pankhurst.]. Cambridge Univ. Press: Cambridge, New York.

Wood, J.R.I., Williams, B.R.M., Mitchell, T.C., Carine, M.A., Harris, D.J. \& Scotland, R.W. 2015a. A foundation monograph of Convolvulus L. (Convolvulaceae). PhytoKeys 51: 1-282.

Wood, J.R.I., Carine, M.A., Harris, D., Wilkin, P., Williams, B. \& Scotland, R.W. 2015b. Ipomoea (Convolvulaceae) in Bolivia. Kew Bulletin 70:31. 